\title{
The Effect of Kombucha Fermentation on Chestnut Cancer Factor (Cryphonectria parasitica (Murrill) E.M Barr)
}

\author{
Ali Savaş BÜLBÜL ${ }^{1 *}$, Esra ATALAN² ${ }^{2}$ Hatice ÜLGEN² ${ }^{2}$ Kevser Betül CEYLAN ${ }^{1}$ \\ ${ }^{1}$ Bartın University, Department of Molecular Biology and Genetic, Bartın, TURKEY \\ ${ }^{2}$ Bartın University, Institute of Science, Bartin, TURKEY \\ *Corresponding author: asavasbulbul@gmail.com
}

Received Date: 21.05.2018

Accepted Date: 08.11.2018

\begin{abstract}
:
Aim of study: Kombucha is a drink obtained by fermentation of sugary tea composed of acetic bacteria and yeast symbiosis. Its effect on prostate cancer and apoptosis, antimicrobial and antioxidant effect in culture medium has been searched. Apart from these studies, the microbial fertilizer property of Kombucha in agriculture has been investigated. In this study, prevention of Cryphonectria parasitica (Murrill) Barr growth by Kombucha tea is aimed.

Area of study: Kombucha was bought commercially. Cancerous samples were obtained from Amasra Topderesi Chestnut Forest (4143'34.2"N-32²4'19.0"E).

Material and Methods: Fungi samples were examined microscopically via Leica DM 750 digital imaging system in vitro. Anatomic characterisation was performed under light microscope

Main results: In vitro Cryphonecteria parasitica growth is prevented to a certain extend via Kombucha fermentation. This effect of Kombucha is thought to be as a result of microbial richness. The aim of this study is to make think that Kombucha can prevent plant diseases and pave the way for more important studies in the future.

Highlights: In this study, prevention of Cryphonectria parasitica growth by Kombucha tea is aimed. It was observed that Kombucha fermentation prevented the growth of Cryphonectria parasitica in vitro.
\end{abstract}

Keywords: Kombucha Fermentation, Chestnut Cancer, Phytopathology, in vitro, Potato Dextrose Agar

\section{Kombucha Fermantasyonun Kestane Kanseri Etmeni (Cryphonectria parasitica (Murrill) E.M Barr) Üzerine Etkisi}

$\ddot{O} \mathbf{z}$

Çalışmanin amacı: Kombucha; asetik bakteri ve maya simbiyozundan oluşan şekerli çayın fermantasyonu ile elde edilen bir içecektir. Kültür ortamında prostat kanseri ve apoptoz üzerine etkisi, antimikrobiyal ve antioksidan etkisi araştırılmıștır. Bu çalışmaların dışında Kombucha'nın tarımda mikrobiyal gübre olma özelliği araştırılmıştır. Bu çalı̧̧mada ise Kombucha çayının, Cryphonectria parasitica (Murrill) Barr'nın gelişimini önlemesi hedeflenmiş̧ir.

Çalışma alanı: Kombucha ticari olarak satın alınmıştır. Kanserli örnekler ise Amasra Topderesi Mevkii Kestane Ormanı'nın (41 $\left.433^{\prime} 34.2^{\prime \prime N}-32^{\circ} 24^{\prime} 19.0^{\prime \prime E}\right)$ dan elde edilmiştir.

Materyal ve Yöntem: Mantar örnekleri invitro ortamda mikroskopik olarak Leica DM 750 dijital görüntüleme sistemi kullanılarak incelendi. Işık mikroskobu (LM) ile anatomik karakterizasyon analizi yapılmıştır.

Sonuçlar: Kombucha fermantasyonu ile in vitro ortamda Cryphonecteria parasitica gelişimi belli bir oranda önlenmiştir. Kombucha'nın bu etkisinin mikrobiyal zenginlikten kaynaklandığ düşünülmektedir. $\mathrm{Bu}$ çalışmanın amacı Kombucha'nın bitki hastalıklarını önlenebileceğini düşündürmek ve ileride daha önemli çalışmaların önünü açmaktır.

Önemli Vurgular: Kombucha fermantasyonun Cryphonectria parasitica'y1 in vitro ortamda gelişimini önlediği gözlenmiştir.

Anahtar Kelimeler: Kombucha Fermantasyonu, Kestane Kanseri, Fitopatoloji, İn vitro, Potato Dextrose Agar 


\section{Introduction}

Chestnuts grow in especially humid, mild, large-leafed forest drainage zones in Black Sea Region in Turkey and sometimes they can be found as pure in this zone (Atasoy and Altıngöz, 2011; Atalay, 2008). Black Sea, Marmara and Aegean Regions are the primary regions of chestnut forests and main regions of collection (Bucak, 2006; Katırcıoğlu, 2010).

Chestnut (Castanea sativa Mill.) trees are spreaded generally in South Europe, East Asia, Europe and east North Amerika. It has nutritional, cultural and economic importance. At the same time, chestnut trees provide eidable fruit and quality timber in many countries such as China, Turkey, Italy and Korea (Dogu, Kose, Kartal \& Erdin, 2011; Metaxas, 2013).

Over the last quarter-century, high consumption demand for chestnut products worldwide caused a rapid increase in both production and trade of this fruit (Atasoy \& Altıngöz, 2011). World chestnut production reached to 1036 tones in 2003. China alone accounts for $69 \%$ of world production whereas Korea second with $7 \%$ and Turkey ranks the third with $5 \%$ in chestnut production (Karahocagil and Tosun, 2004).

The production of chesnuts was 45.000 tones in 1978 and reached to 90.000 tones in 1987 and 1988, after these years, although it decreased to 73.000 tones in 1989 and 50.000 tones in 2002'a linear increase is seen in production volume (Aksoy, Serdar \& Soylu, 2005; Gülcan et al., 2000). This decrease in chestnut production in our country is originated from chestnut cancer (Aksoy et al., 2005).

At the beginning of the XX. century, chestnut cancer which comes to the fore and spread rapidly in USA and caused death of most of USA chestnuts till 1950's (Atasoy \& Altıngöz, 2011; Soylu, 2004).

Chestnut has promising carbon isolation and is resistant to rotting. Capture and slow release of carbon, makes these trees very compatible in carbon digestion capability compared to other trees. If feed backed, it can play an important role in fight with climate change (Ellison, 2005; Jacobs, Selig \& Severeid, 2009; Jacobs and Severeid, 2004). Chestnut cancer, is the most important disease of chestnut trees and is frequently seen in World's and Turkey's chestnut zones.
Most of the time it is a major problem causing the trees to dry completely (Çeliker and Onoğur, 2011).

Cryphonectria parasitica, is an ascomycota fungi which can form dicarion when hold together fungal colonies and hyphae of different populations (Marra and Milgroom, 2001; Florjanczyk, Barnes, Kenneyand \& Horzempa, 2006). Branches of chestnut trees produce spores that spread to other trees by wind (Marra et al., 2001; Florjanczyk et al., 2016). Spores enter to open wounds in root tissue and the fungus growth goes along with oxalic acid (OA) release. This causes a decrease in $\mathrm{pH}$ of chestnut tissue (Zhang, 2013; Florjanczyk et al., 2016). Decreased $\mathrm{pH}$ levels, at the same time inhibits the function of chestnut tissue and this causes cancer genesis (Zhang, 2013; Chen, Sun, Narayanan, Nuss \& Herzberg, 2010; Florjanczyk et al., 2016). As a result of cancer growth, food flow within the tissue is disrupted and tree dies in time (Zhang, 2013; Newhouse, 1990; Griffin, 1986; Florjanczyk et al., 2016). The most effective control method in fight with chestnut cancer up to today is the use of hypovirulent (forming disease with low severity) strains in biological control of the pathogen (Erincik, Özdemir, Durdu, Döken \& Açıkgöz, 2011). Biological control via hypovirulent strains is a widely used control method for chestnut cancer and is successfully applied as a remedial measure in many countries (Ak1ll1, Katırcıoğlu \& Maden, 2011). In this method, hypovirulent and virulent strains should be compatible for fight (Avgan, 2013). New fight methods are necessary for chestnut cancer. In our study, a fight method against chestnut cancer factor via Kombucha fermentation was tried.

Kombucha is a very popular, traditional fermented drink consumed through the world (Sreeramulu, Zhu \& Knol, 2000). This drink was originated from China, Korea and Japan in B.C. 220. It was defined as Kombucha because of Dr. Kombu who brought tea fungus from Korea to Japan (Loncar, Djuric, Malbasa, Kolarov \& Klasnja, 2006). Kombucha is pretty appropriate and useful for production and attaining; because once Kombu fungus is obtained, it produces offspring once a week as a result of brewing. This offspring gradually thickens when waited long time and becomes main Kombu 
fungus. Thus Kombucha is not an expensive method and easy to obtain. Kombucha is a drink obtained by fermentation of sugary tea which is composed of acetic bacteria and yeast symbiosis (Battikh, Bakhrouf \& Ammar, 2012). Tea fungus "Kombucha", is a symbiotic association of different yeasts [Brettanomyces lambicus (Kuff. \& Van Laer), Brettanomyces bruxellensis (Kuff. \& Van Laer ex Custers), Brettanomyces custersii (Florenz.), Saccharomyces cerevisiae (Desm. Meyen), Schizosaccharomyces pombe (Lindner), Kloeckera apiculata (Reess) Janke), Zygosaccharomyces bailii (Lindner Guillierm.), Saccharomycodes ludwigii (E.C. Hansen), Zygosaccharomyces kombuchaensis sp. (Kurtzman, Robnett \& Bas.-Powers), Zygosaccharomyces rouxii (Boutroux Yarrow)] and acetic acid bacteria [Acetobacter aceti (Pasteur), Acanthodica xylinoides (Schaus, 1894), Acetobacter pasteurianus (Hansen Beijerinck and Folpmers), Acetobacter xylinum (Brown Yamada), Bacterium gluconicum (Hermann), Gluconobacter oxydans (Henneberg)] (IleriBüyükoğlu, Taşçı and Şahin-Dokuyucu, 2010). Although the yeast composition of Kombucha colony is variable, Zygosaccharomyces and Saccharomyces are the most frequent species. It is reported that bacteria primarily produce cellulose, acetic acid, gluconic acid (Greenwalt, Steinkraus \& Ledford, 2000; İleri-Büyükoğlu et al., 2010). The rich content of Kombucha has brought the feature of becoming microbial fertilizer in 2016. In the study of searching the opportunity of Kombu (Kombucha) and Kombu tea production waste mixed microorganism culture in agriculture as fertilizer leaded these results; Kombu tea and lyophilized waste Kombu tea culture was used for the effect on wheat plant efficiency and change of biological properties in the soil. As a result, it was seen that lyophilized waste Kombu tea cultures positively affected the dehydrogenase (an intracellular enzyme showing the total oxidative activity of the soil microflora) activity in both sandy loamy and loamy soil so increased microbiological activity of the soil (Skujins, 1973; Trevors, 1984; Durmuş and Kızılkaya, 2016; Akata, Kabaktepe, Sevindik \& Akgül, 2018; Özkan, Olgun, Güney, Gür, Güney \& Ateş, 2018).
Hence, according to the obtained results, application of Kombucha to the soil in increasing levels enhanced the soil respiration amount in both sandy loamy and loamy soil (Durmuş \& Kızılkaya, 2016). In another study, it was determined that acetic acid and $0.5 \%$ Kombucha inhibit 10 out of 14 bacteria in the same way. It was understood that, Kombucha shows strong antimicrobial effect to other 4 bacteria (Escherichia coli (Migula), Salmonella enteritidis (Gaertner Castellani and Chalmers), Salmonella typhimurium (Loeffler Castellani and Chalmers) and Shigella sonnei (Levine Weldin) and these effects can be seen even at pH 7 after heating. (İleri-Büyükoğlu et al., 2010). As can be understood from these conducted studies, Kombucha can be used as active ingredient for the fight against disease factors.

In our study, it was aimed to investigate if the chestnut cancer factor Cryphonecteria parasitica can be inhibited and to lead up for a new fight method aganist chestnut cancer, also to provide more frequent use of Kombucha fermentation in studies.

\section{Material and Method}

Kombucha was bought commercially. Cancerous samples were obtained from Amasra Topderesi Chestnut Forest $\left(41^{\circ} 43^{\prime} 34.2^{\prime \prime} \mathrm{N} 32^{\circ} 24^{\prime} 19.0^{\prime \prime} \mathrm{E}\right)$. Pieces were obtained with using lancet. Fungi samples were examined microscopically via Leica DM 750 digital imaging system. Anatomic characterisation analysis was performed under light microscope (Gündüz et al., 2016).

\section{Isolation of $C$. parasitica from Chestnut Tree}

Pieces taken from diseased regions of chestnut tree were divided into sections 2-5 $\mathrm{mm}$ in size. Surface sterilization of these pieces was done by keeping at first $1 \%$ sodium hypochlorite $(\mathrm{NaClO})$ at least 1 minutes and then by keeping in sterile distilled water at least for one minute The dried pieces were placed in petri dishes containing PDA (Potato Dextrose Agar) as 3 pieces per petri plate. Petri plates were incubated for 7 days at $24-25^{\circ} \mathrm{C}$ and then exposed to daylight for 5-7 days (Avgan, 2013). 


\section{Determination of Virulency of $C$. parasitica \\ Cultural Properties}

In order to specify the cultural properties of isolated Cryphonectria parasitica spore isolates, all isolates were cultured in PDA. Petri plates were incubated for 7 days in dark at $25^{\circ} \mathrm{C}$ and then for 5-7 days in daylight. Under these conditions, virulent isolates growed as orange colour while hypovirulent isolates growed as white (Bissegger, Rigling \& Heiniger., 1997; Ak1ll1, 2008). By this way virulent and hypovirulent isolates were discriminated.

\section{Apple Test}

Surfaces of Golden type apples were wiped with alcoholed cotton. Pieces were removed from steady surfaces of each apple and micellious surfaces of $C$. parasitica isolates which were incubated at dark for seven days in PDA were placed in apples. Apples were coated with cling wrap and incubated at $23-24^{\circ} \mathrm{C}$ in dark for 15 days (Ak1llı, 2008).

\section{Bavendam Test}

Bavendamm medium (5 g Tannic acid, 15 $\mathrm{g}$ Malt extract, $20 \mathrm{~g}$ Bacto agar, 1L distilled water) was prepared. Malt extract agar and tannic acid solutions were prepared and autoclaved separately and then mixed before pouring to petri plates. Discs taken from fungi isolates that were grown in PDA were transferred to this medium and incubated for 4 days in dark at $20^{\circ} \mathrm{C}$. After 4 days the ones showing dark color reaction were evaluated as virulent while the ones showing light color reactions or no reactions were evaluated as hypovirulent (Ak1ll1, 2008).

\section{Application of Kombucha to C. parasitica}

$245 \mathrm{~g}$ sugar was added to boil in $3 \mathrm{~L}$ water. After it dissolved, 10 bags of black tea was added and waited for 1 hour. At the end of 1 hour, tea bags were removed and prepared tea left for cooling. Cooled tea was added to Kombucha and fermented tea (taken from tea fermented before).

Samples were taken from $C$. parasitica stock were inoculated new PDAs. Disc soaked with unfermented tea and placed on inoculalated petri plate was used as negative control $\left(\mathrm{pH}_{\text {Normal tea: }}\right.$ 4.57). C. parasitica inoculated petri plate was used as positive control. The experimental group was petri plates with Kombucha tea soaked discs $\left(\mathrm{pH}_{\text {Kombucha tea: }}\right.$ 3.72). This experiment was performed as triplicate.

\section{Results}

Examples of cancerous chestnut trees to be used in our study were collected from Amasra Topderesi Province Chestnut Forest $\left(41^{\circ} 43^{\prime} 34.2^{\prime \prime N} 32^{\circ} 24^{\prime} 19.0^{\prime \prime} \mathrm{E}\right)$ (Figure 1). The light microscope image of $C$. parasitica is shown in figure 2 .
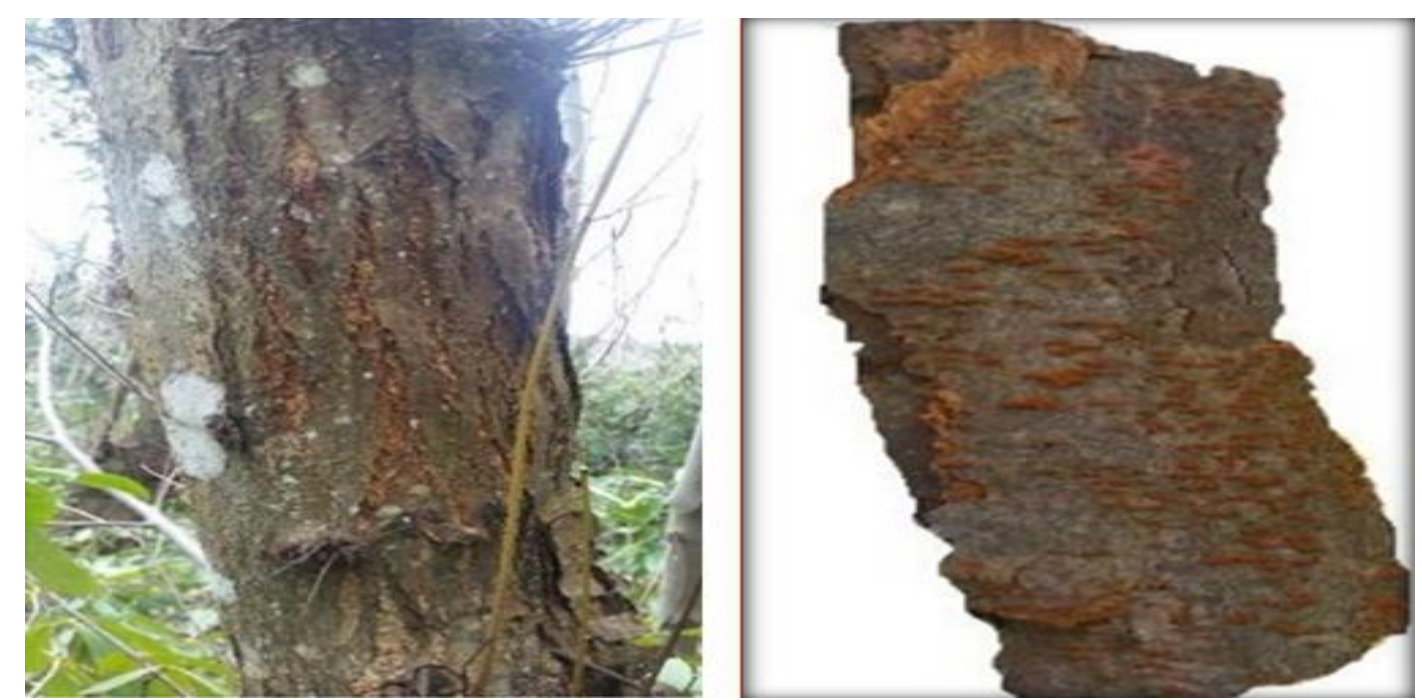

Figure 1. Amasra Topderesi Province Chestnut forest $\left(41^{\circ} 43^{\prime} 34.2^{\prime \prime N}-32^{\circ} 24^{\prime} 190^{\prime \prime E}\right)$ is also shown with a cancer chestnut tree on the left, with the tree taken on the right. 

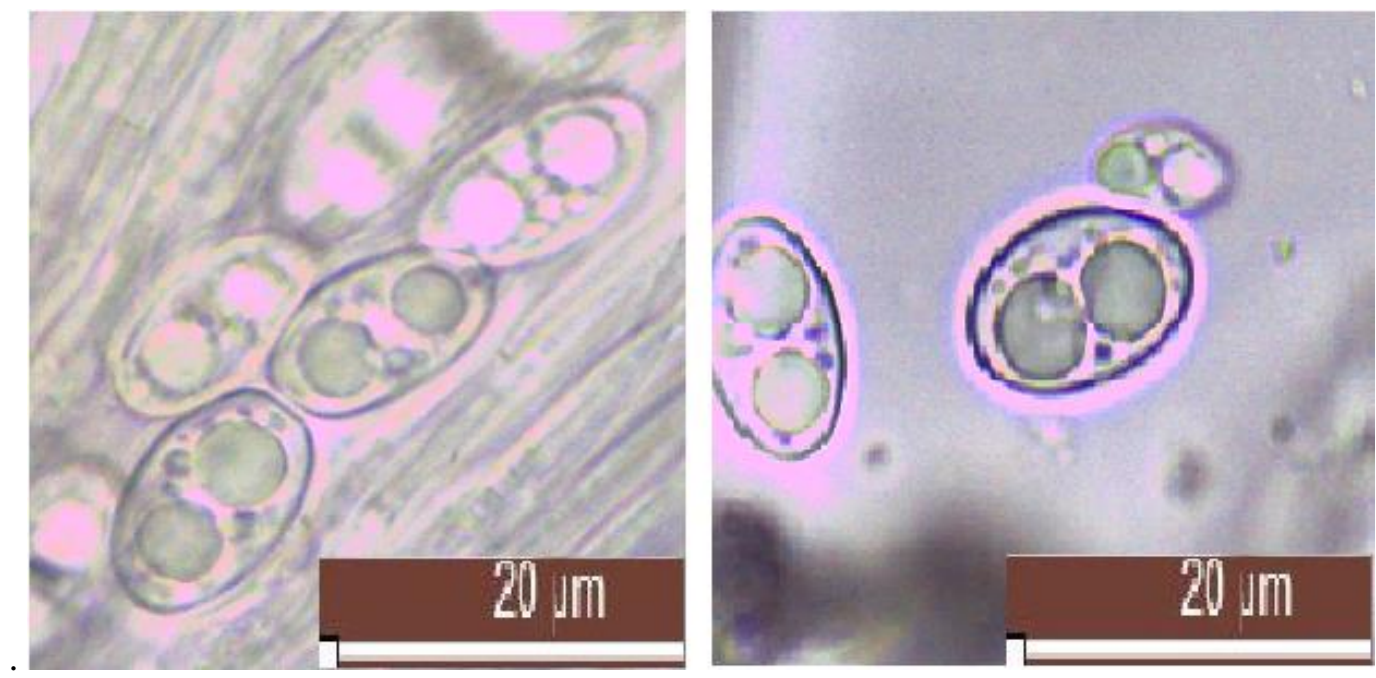

Figure 2. Image of Cryphonectria parasitica under light microscope (Gündüz et al., 2016).

"Ascospore features of Cryphonectria parasitica (Murrill): Stromata diffuse, valsoid, yellow to yellowish brown, brownish red, prosseximous, $3 \mathrm{~mm}$ wide and $2.5 \mathrm{~mm}$ high (Gündüz et al., 2016).

Determination of Virulency of $C$. parasitica

\section{By Cultural Properties}

In order to determine the virulence of $C$. parasitica, it was first attempted to determine its cultural characteristics. It is accepted that hypovirulent isolates of low virulent isolates
C. developing in white color and virulent isolates emerging in orange color in culture. (Katırcioğlu, 2010).

The results obtained after culturing $C$. parasitica isolates cultured in PDA medium at $25^{\circ} \mathrm{C}$ for 7 days in darkness and 5-7 days in daylight are shown in Fig. 3.
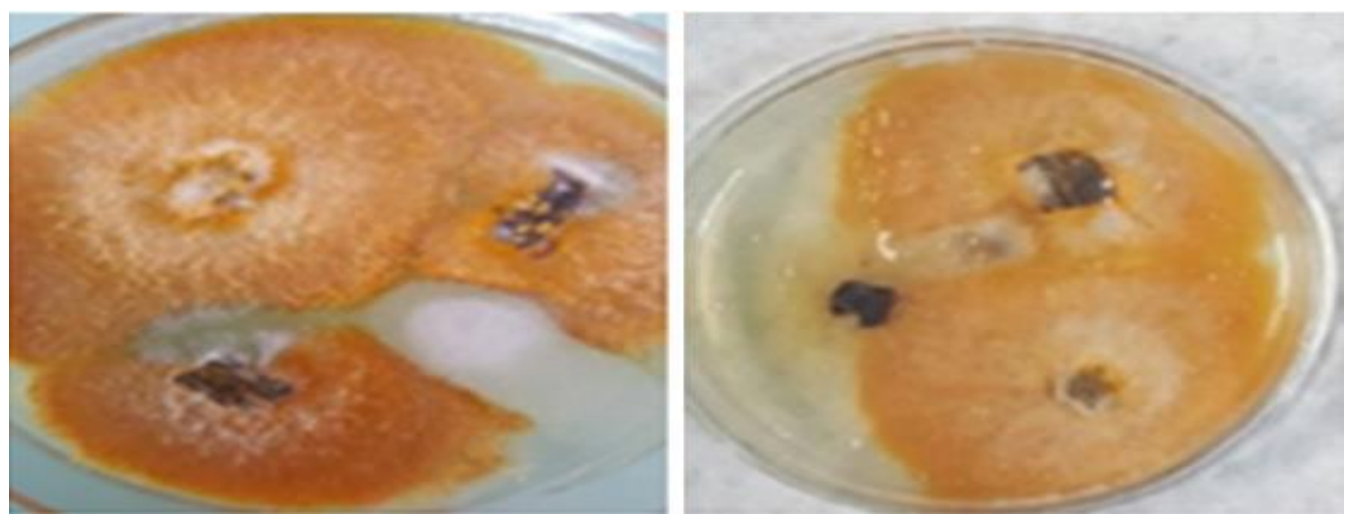

Figure 3. The appearance of the Cryphonectria parasitica isolates obtained from isolation from the patient chestnut branches. The orange color in the picture is predicted from previous studies that may be virulent.

\section{Apple Test}

The results obtained after standing for 15 days in the dark at $23-24{ }^{\circ} \mathrm{C}$ are shown in figure 4 , where the $C$. parasitica isolates were placed. 


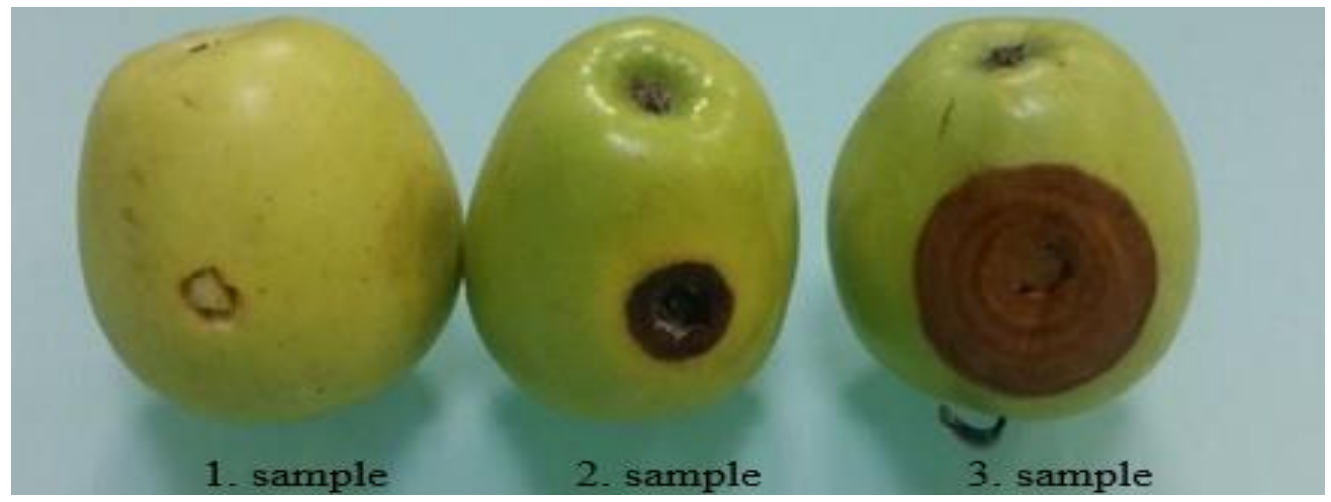

Figure 4. Parts from C. parasitica isolates grown in the PDA (Patato Dextrose Agar) medium were placed in the apple. The next image of the apples that are left for 15 days is shown.

In Fig. 4, apple number 1 is used as a control. The apple test is considered to be less sensitive than the other tests, since the pathogen is not applied in the native host chestnut.

\section{Bavendam Test}

Discs from fungus isolates were placed in the Bavandam media prepared according to Ak1ll (2008). After four days, the dark colors in the medium were evaluated as virulent (Figure 5).

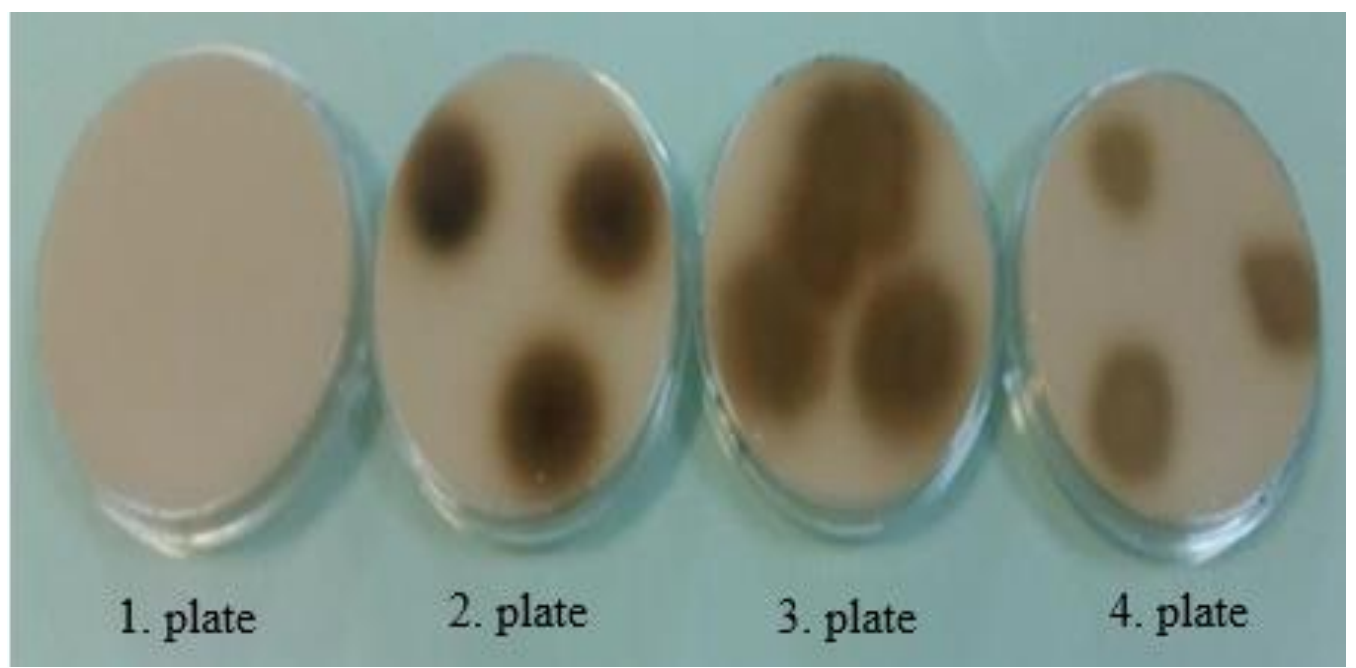

Figure 5. In the Bavandam test, dark colored ones show virulent isolates. Petri dish number 1 is control group.

According to the results, it was understood that tested isolates show virulency in all three tests and then Kombucha was applied to virulent isolates.

\section{Application of Kombucha to C. parasitica}

By looking at the studies for determination of $C$. parasitica virulency, it was understood that obtained isolates are virulent. In our study, effect of Kombucha on virulent strain of $C$. parasitica was investigated.

The discs that were sucked by Kombucha tea were placed the media of $C$. parasitica by streak plate method (Fig. 6). On the seventh and eighth day, the zone diameters were measured and shown in Table 1. 

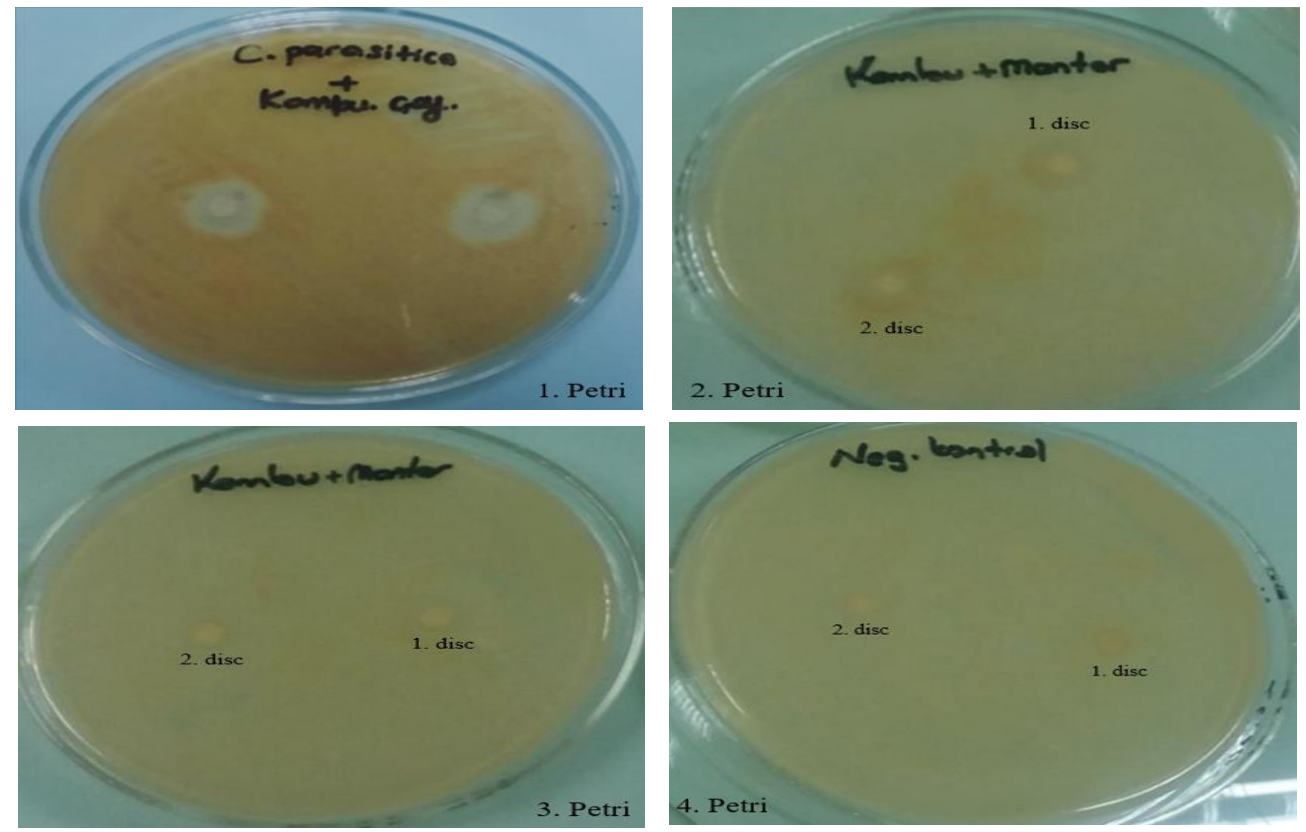

Figure 6. Kombucha impregnated Discs were placed on C. parasitica in PDA. Zones were measured at 7. and 8. day and data were shown in Table 1.

Table 1. Effect of Kombucha impregnated discs on C. parasitica

\begin{tabular}{|c|c|c|c|}
\hline & DISC & $\begin{array}{lrl}\text { Zone diameters } & (\mathrm{mm}) \\
\text { measured on day } 7 & \end{array}$ & $\begin{array}{l}\text { Zone diameters }(\mathrm{mm}) \\
\text { measured on day } 8\end{array}$ \\
\hline \multirow[b]{2}{*}{ 1. Petri dish } & 1.Disc & 17 & 17 \\
\hline & 2.Disc & 12 & 12 \\
\hline \multirow[b]{2}{*}{ 2. Petri dish } & 1.Disc & 16 & 17 \\
\hline & 2.Disc & 9 & 10 \\
\hline \multirow{2}{*}{ 3. Petri dish } & 1.Disc & 9 & 9 \\
\hline & 2.Disc & 10 & 10 \\
\hline \multirow{2}{*}{$\begin{array}{l}\text { 4. Petri dish } \\
\text { (Negative control) }\end{array}$} & 1.Disc & No zones & No zones \\
\hline & 2.Disc & No zones & No zones \\
\hline
\end{tabular}

Zone diameters were measured on the seventh and eighth days after disposing of discs soaked with $C$. parasitica by spread plate method. Zone diameters measured on day 7: $17 \mathrm{~mm}$ and $12 \mathrm{~mm}$ for 1st petri dish; 1 $6 \mathrm{~mm}$ and $9 \mathrm{~mm}$ 2nd petri dish; $9 \mathrm{~mm}$ and 10 $\mathrm{mm}$ for 3 rd petri dish. On the eighth day, the diameter of the disc in the second petri dish was measured to increase by $1 \mathrm{~mm}$ (Table 1). Discs soaked with only tea were placed in 4th petri dish. As observed in previous studies, it was once again seen that it was not the effect of nonfermented tea.

\section{Discussion and Conclusion}

The most important method in fighting with chestnut cancer is the use of hypovirulent strains. Hypovirulent strains are widely used control methods for chestnut cancer and is applied successfully as a healing measure in many countries. These studies are also conducted in our country. Hypovirulent and virulent strains should be compatible in order to apply this method successfully. These studies should be enhanced and new methods should be found. Methods of weaken chestnut cancer factor by in vitro condition should be applied.

In our study, fight against chestnut cancer was considered from a different viewpoint and Kombucha fermentation was used for treatment. Many components produced by Kombucha fermentation have allowed Kombucha to be used in scientific studies. Studies about Kombucha are increasing day by day and Kombucha is an important drink all around the world (Sreeramulu et al., 2000).

Kombu tea and lyophilized Kombu tea cultivation were applied to wheat plant under two different soil greenhouse conditions. It was determined that the Kombu tea and 
lyophilized Kombu tea cultivation applied at greenhouse increase the yield of the wheat plant. At the same time, it was observed that the biologic propertie of soil increased. It is thought that kombucha tea improves the yield of wheat by preventing disease factors that may exist in wheat plant. Kombucha tea suggests that this effect is due to its rich content, which also reveals the need for a phytopathological examination of Kombucha tea (Durmuş \& Kızılkaya, 2016).

In another study, it was determined that acetic acid and $0.5 \%$ Kombucha tea inhibited ten of fourteen bacteria in the same way [Staphylococcus aureus (Rosenbach), Shigella sonnei (Levine Weldin), Escherichia coli (Migula), Aeromonas hydrophila (Chester), Yersinia enterocolitica (Schleifstein \& Coleman), Pseudomonas aeruginosa (Schroeter), Enterobacter cloacae (Jordon 1890), Staphylococcus epidermis (Castelllani and Chalmers), Campylobacter jejuni (Jones, Orcutt and Little), Salmonella enteritidis (Gaertner Castellani and Chalmers), Salmonella typhimurium (Loeffler Castellani and Chalmers), Bacillus cereus (Frankland and Frankland), Helicobacter pylori (Marshall et al.) and Listeria monocytogenes (Murray, Webb and Swann)]. The other four bacterial strains [Escherichia coli (Migula), Salmonella enteritidis (Castelllani and Chalmers), Salmonella typhimurium (Loeffler Castellani and Chalmers) and Shigella sonnei (Levine)] showed strong antimicrobial effects of Kombucha tea, it was understood that it was seen even at $\mathrm{pH} 7$ after heating (İleri-Büyükoğlu et al., 2010). According to these studies, Kombucha tea can be used as an active ingredient in the fight against disease factors. The increase in wheat productivity of Kombucha tea has led us to investigate the phytopathologic direction of Kombucha tea.

Due to the rich microbial content of Kombucha, trial on wheat plant and increasing efficiency in wheat plant is remarkable and wider studies should be conducted about microbial fertilizer usage of Kombucha. Kombucha is very convenient and useful for production and obtaining. Once Kombu fungus is obtained, it gives one offspring in one week when brewed with tea. If this offspring is kept in fermented tea for a long time, it gradually thickens and becomes mother Kombu fungus. That's why, Kombucha is not an expensive method and it is easy to obtain and use of Kombucha should not be ignored in studies.

With the Kombucha fermentation, the development of Cryphonectria parasitica was prevented at a certain time by in vitro method. This effect of Kombucha is thought to be as a result of microbial richness. This study aims to show that plant diseases such as chestnut cancer can be prevented by natural and biological ways such as Kombucha tea and that further applications in this field can be done.

\section{References}

Akata, I., Kabaktepe, Ş., Sevindik, M. \& Akgül, H. (2018). Macrofungi determined in Yuvacik Basin (Kocaeli) and its close environs. Kastamonu University Journal of Forestry Faculty, 18(2), 152-163.

Akıll1, S. (2008). Researches on The Biological Control of Chestnut Blight (C. parasitica) in Black Sea Region. Ankara University, Graduate School Of Natural And Applied Sciences, Doctoral Dissertation, (s.88).

Akıllı, S., Katırcıoğlu, Y. Z. \& Maden, S. (2011). Biological Control of Chestnut Canker, Caused by Cryphonectria parasitica, by Antagonistic Organisms and Hypovirulent Isolates. Turkish Journal of Agriculture and Forestry, 35: 515- 523.

Aksoy, H. M., Serdar, Ü. \& Soylu, A. (2005). Various Control Methods Used Against Chestnut Blight (Cryphonectria parasitica (Murrill) Barr) in Chestnut Grafted Trees. Journal of Agricultural Faculty of Ondokuz Mayıs University, 20(1): -24-29.

Atalay, İ. (2008). Ecosystem Ecology and Geography, Meta Basim ve Matbaacilık Hizmetleri, İzmir.

Altuner, E. \& Çetin, B. (2018). Antimicrobial activity of Isothecium alopecuroides and potential effect of some climate elements on the activity of this bryophyte sample. Kastamonu University Journal of Forestry Faculty, 18(2), 126-137.

Atasoy, E. \& Altıngöz, Y. (2011). The Importance of Chestnut and Production İn Turkey And World. Journal of Geography, 22, 1-13.

Avgan, N. (2003). The Studies on Biological Control of Chestnut Blight Caused by Cryphonectria parasitica (Murr.) Barr. in Bursa Province of Turkey. Uludağ University, Graduate School of Natural and Applied Sciences, Master Thesis, 57s.I

Battikh, H., Bakhrouf, A. \& Ammar, E. (2010). Antimicrobial effect of Kombucha analogues, 
Uludag University Journal of the Faculty of Veterinary Medicine, 29(1), 69-76.

Bissegger, M., Rigling, D. \& Heiniger, U. (1997). Population structure and disease development of Cryphonectria parasitica European chestnut forest in the presence of natural hypovirulence. Phytopathology, 87, 50-59.

Bucak, C. (2006). Distribution of Natural Chestnut (Castanea sativa Mill.) Stands of Turkey and Suggestions for Protection. Ege Ormancılık Araştırma Müdürlüğü Yayınları. İzmir. 62-82.

Chen, C., Sun, Q., Narayanan, B., Nuss, D. L. \& Herzberg, O. (2010). Structure of Oxalacetate Acetyl Hydrolase, A Virulence Factor of the Chestnut Blight Fungus. The Journal of Biological Chemistry. 285: 26685-26696.

Çeliker, N. M. \& Onoğur, E. (2011). Promising Results On Biological Control of Chestnut Blight in Turkey. Journal of Agricultural Sciences, 17, 122-130.

Durmuş, M. \& Kızılkaya, R. (2016). Effect of Kombu Tea (Kombucha) and Mix Microorganisms Culture of Kombu Tea Production Waste on Wheat Plant Yield, Dehydrogenase And Catalase Enzyme Activity of Soils, Ondokuz Mayıs University, Faculty of Agriculture, Journal of Soil Science and Prefeeding, 4(2), 76-82.

Dogu, D., Kose, C., Kartal, S. N. \& Erdin, N. (2011). Wood Identification of Wooden Marine Piles from the Ancient Byzantine Port of Eleutherius/Theodosius. Bioresources, 6, 987-1018.

Ellison, A. M. (2005). Loss of Foundation Species: Consequences for the Structure and Dynamics of Forested Ecosystems. Frontiers in Ecologyand the Environment, 3, 479-486.

Erincik, Ö., Özdemir, Z., Durdu, Ö.F., Döken, M.T. \& Açıkgöz S. (2011). Diversity and spatial distribution of vegetative compatibility types and mating types of Cryphonectria parasitica in the Aydin Mountains, Turkey. The European Journal of Plant Pathology, 129, 555-566.

Florjanczyk, A., Barnes, R., Kenneyand, A. \& Horzempa, J. (2016). Soluble Material Secreted From Penicillium Chrysogenum Isolate Exhibitsanti Fungal Activity Against Cryphonectria parasitica- Thecausative Agent of The American Chestnut Blight. Department of Natural Sciencesand Mathematics.

Greenwalt, C. J., Steinkraus, K. H. \& Ledford, R. A. (2000). Kombucha, The Fermented Tea: Microbiology, Composition, and Claimed Health Effects. Journal of Food Protect, 63, 976-981.

Griffin, G. J. (1986). Chestnut Blight and its Control. Horticultural Reviews, 8, 291-336.
Gülcan, R., Tekintaş, F. E., Mısırlı, A., Sağlam, H., Günver, G. \& Adanacioğlu, H. (2000). Production Targets in Fruit Production. Tagem. 587-616.

Gündüz, G., Oral, M. A., Akyuz, M., Aydemir, D., Yaman, B., Asik, N., Bulbul, A. S. \& Allahverdiyev, S. (2016). Physical, Morphological Properties and Raman Spectroscopy of Chestnut Blight Diseased Castanea satıva Mill. Wood. Cerne. 01047760.

Jacobs, D. F. \& Severeid, L. R. (2004). Dominance of interplanted American Chestnut (Castanea dentata) in South Western Wisconsin, Usa. Forest Ecology and Management, 191, 111-120.

Jacobs, D. F., Selig, M. F. \& Severeid, L. R. (2009). Above Ground Carbon Biomass of Plantation-Grown American Chestnut (Castanea dentata) in Absence of Blight. Forest Ecology and Management, 258, 288294.

Karahocagil, P. \& Tosun, İ. (2004). Chestnut. Agricultural Economics Research Institute, 7(13), ISSN 1303-8346.

Katırcioğlu, Y. Z. (2010). Researches on the Biological Control of Chestnut Canker in Black Sea Region of Turkey. Project Executive: Prof. Dr. Yakup Zekai Katırcıoğlu. Project Members: Prof. Dr. Salih Maden, Yrd. Doç. Dr. Seçil Akıllı, Doç. Dr. Çiğdem Ulubaş Serçe. Project Number: 06 B 4347004

Loncar, E., Djuric, M., Malbasa, R., Kolarov, L.J. \& Klasnja, M. (2006). Influence of working conditions upon Kombucha conducted fermentation of black tea. Food and Bioproducts Processing, 84, 186-192.

Marra, R. E. \& Milgroom, M. G. (2001). The Mating System of the Fungus Cryphonectria parasitica: Selfing And Self-Incompatibility. Heredity (Edinb urgh), 86, 134-143.

Metaxas, A. M. (2013). Chestnut (Castanea spp.) Cultivar Evaluation for Commercial Chestnut Production in Hamilton County. Dissertation (Master of Science in Environmental Science)- Faculty of The University of Tennessee, Tennessee.

Newhouse, J. R. (1990). Chestnut Blight. Scientific American, 263, 74-79.

Özkan, O.E., Olgun, Ç., Güney, B., Gür, M., Güney, K. \& Ateş, S. (2018). Chemical composition and antimicrobial activity of Myristica fragrans \& Elettaria cardamomum essential oil. Kastamonu University Journal of Forestry Faculty, 18(2), 225-229.

Skujins, J. (1973). Dehydrogenase: An indicator of biological activities in arid soil. Bulletin Ecological Communication (Stockholm), 17, 97-110. 
Soylu, A. (2004). Chestnut Breeding And Characteristics. Hasad Yayıncllı Limited Şirketi, 64. İstanbul.

Sreeramulu, G., Zhu, Y. \& Knol, W. (2000). Kombucha fermentation and its antimicrobial activity. Journal of Agricultural and Food Chemistry, 48, 2589-2594.

İleri-Büyükoğlu, T., Taşçı, F. \& Şahin-Dokuyucu, F. (2010). Kombucha and the Effects on Health. Uludag University Journal of the Faculty of Veterinary Medicine, 1, 69-76.
Trevors, J. T. (1984). Dehydrogenase activity in siol. A comparison between the INT and TTC assay. Soil Biology and Biochemistry, 16, 673674.

Zhang, B. (2013). A Threshold Level of Oxalate Oxidase Transgene Expression Reduces Cryphonectria parasitica- Induced Necrosis in a Transgenic American Chestnut (Castanea dentata) Leaf Bioassay. Transgenic Research, 22, 973-982. 